\title{
Early Christian Prayer and Identity Formation
}

\author{
Ed. by Reidar Hvalvik and Karl Olav Sandnes
}

[Frühchristliche Gebete und Identitätsbildung.]

Veröffentlicht auf Englisch.

Die Beiträger dieses Bandes behandeln die Frage der Identität unter gläubigen Christen aus der Perspektive des Gebets. Das Gebet bringt verschiedene Dimensionen ins Spiel, aus denen religiöse Identität entsteht. Es gibt frühe Zeugnisse davon, dass das Gebet »praktizierte Theologie« war und dadurch mit aufkommenden Theologien verflochten war. Des Weiteren war Beten in Ausrichtung und Schwerpunkt christozentrisch. Diese Aspekte haben in der wissenschaftlichen Diskussion bisher nicht die angemessene Aufmerksamkeit erhalten. Die christliche Identität, wenngleich fragil und komplex, nahm bereits im ersten Jahrhundert Gestalt an und stand zwischen textuellem Phänomen und sozialer Realität. Die Texte hatten Einfluss auf diejenigen, die ihnen ausgesetzt waren und schufen eine Darstellung der sozialen Realität, können aber nicht einfach mit dieser Realität identifiziert werden. Texte über Gebete sind präskriptiv, indem sie bestimmte Gedanken der christlichen Identität empfehlen und den Leser einladen, bestimmte Denk- und Verhaltensmuster zu übernehmen. Dieser Band geht diesem Vorgang auf den Grund.

\section{Inhaltsübersicht}

Reidar Hvalvik/Karl Olav Sandnes: Early Christian Prayer and Identity Formation: Introducing the Project - Mikael Tellbe: Identity and Prayer - Larry Hurtado: The Place of Jesus in Earliest Christian Prayer and its Import for Early Christian Identity Reidar Hvalvik: Praying with Outstretched Hands: Nonverbal Aspects of Early Christian Prayer and the Question of Identity Geir Otto Holmås: Prayer, 'Othering' and the Construction of Early Christian Identity in the Gospels of Matthew and Luke Mikael Tellbe: Prayer and Social Identity Formation in the Letter to the Ephesians - Anna Rebecca Solevåg: Prayer in Acts and the Pastoral Epistles: Intersections of Gender and Class - Ole Jacob Filtvedt: With Our Eyes Fixed on Jesus: The Prayers of Jesus and His Followers in Hebrews - Craig R. Koester: Heavenly Prayer and Christian Identity in the Book of Revelation - Karl Olav Sandnes: "The First Prayer «: Pater Noster in the Early Church - Hans Kvalbein: The Lord's Prayer and the Eucharist Prayers in the Didache - Reidar Aasgaard: „What point is there for me in other people hearing my confessions?« Prayer and Christian Identity in Augustine's Confessions - Anastasia Maravela: Christians Praying in a Graeco-Egyptian Context: Intimations of Christian Identity in Greek Papyrus Prayers - Niclas Förster: Prayer in the Valentinian Apolytrosis: A Case Study on Gnostic Identity - Glenn Wehus: »Bring Now, O Zeus, What Difficulty Thou Wilt. » Prayer and Identity Formation in the Stoic Philosopher Epictetus - Reidar Hvalvik/Karl Olav Sandnes: Prayer and Identity Formation: Attempts at a Synthesis

Karl Olav Sandnes Born 1954; 1988 Dr.theol.; 1984-91 teacher at the School of Mission and Theology, Stavanger; 1991-93 visiting professor at the Lutheran Theological Seminary, Hong Kong; since 1993 Professor at MF Norwegian School of Theology; 2013 visiting professor Nanjing Union Theological Seminary, PR China.

Reidar Hvalvik Born 1951; 1994 Dr.theol.; 1994-2005 Associate Professor, since 2005 Professor in New Testament studies at MF Norwegian School of Theology; 2006-07 Research Professor at the Norwegian Institute in Rome.

Jetzt bestellen:

https://mohrsiebeck.com/buch/early-christian-prayer-and-identity-formation-9783161535215?no_cache=1 order@mohrsiebeck.com

Telefon: $+49(0) 7071-923-17$

Telefax: +49 (0)7071-51104 